\title{
Pathomorphological alterations in sheatfish fry Silurus glanis experimentally infected with an iridovirus-like agent
}

\author{
M. Ogawa ${ }^{1}$, W. Ahne ${ }^{1}$, T. Fischer-Scherl ${ }^{1}$, R. W. Hoffmann ${ }^{1}$, H. J. Schlotfeldt ${ }^{2}$ \\ ${ }^{1}$ Institute of Zoology and Hydrobiology of the University of Munich, Kaulbachstr. 37, D-8000 München 22, Germany \\ ${ }^{2}$ State Fish Epidemics Control Service of Lower Saxony and Fish Health Service, Eintrachtweg 17, D-3000 Hannover, Germany
}

\begin{abstract}
An iridovirus-like agent isolated from sheatfish Silurus glanis fry was used for infection trial. Sheatfish fry exposed to the water-borne virus exhibited anorexia, apathy, and ataxia. Mortality reached $100 \%$ within $8 \mathrm{~d}$ at $25^{\circ} \mathrm{C}$. Gross signs of the infection were petechial haemorrhages in the skin and internal organs. A generalized destruction of the haematopoietic tissues of spleen and kidney was prominent among infected fish. Virus particles were observed in the cytoplasm of endothelial, epithelial, and white blood cells in different organs. The virus could be reisolated from infected fish with infectivity titers of up to $8.2 \log _{10} \operatorname{TCID}_{50} \mathrm{ml}^{-1}$.
\end{abstract}

\section{INTRODUCTION}

The sheatfish Silurus glanis is a new candidate for food fish aquaculture in Europe. These fish are usually raised in warm-water aquaculture units, often under crowded conditions. Four pathogenic viruses have been found in sheatfish so far: spring viremia of carp virus (Fijan et al. 1981), a herpesvirus associated with skin lesions (Békési et al. 1981), pike fry rhabdovirus (Jørgensen et al. 1989), and an icosahedral cytoplasmic deoxyribovirus isolated from an epizootic in sheatfish fry in a Lower Saxony (Germany) warm-water aquaculture unit (Ahne et al. 1989, 1990). The latter iridovirus-like agent killed $100 \%$ of sheatfish fry within $1 \mathrm{wk}$ at a water temperature of $25^{\circ} \mathrm{C}$ (Ahne et al. 1990). As little is known about this disease a study on the pathogenesis of this virus infection was undertaken. In this paper we describe pathomorphological alterations caused by the virus in different organs of experimentally infected sheatfish.

\section{MATERIAL AND METHODS}

Infection experiments. Healthy 4 to $5 \mathrm{~cm}$ sheatfish fry were obtained from a commercial fish farm in Lower Saxony. They were maintained in groups of 100 fish in
$100 \mathrm{l}$ aquaria with recirculating water systems $\left(24 \pm 1^{\circ} \mathrm{C}\right)$ and fed with commercial dry food.

Random samples of fish were routinely checked and no evidence of parasites, bacteria, or viruses was found.

The virus (Ahne et al. 1989) used for the infection experiment (3rd BF-2 passage) was propagated in BF-2 cells at $25^{\circ} \mathrm{C}$.

One hundred sheatfish fry were exposed to the virus by immersion in a $5 \mathrm{l}$ aerated tank containing $10^{55}$ $\mathrm{TCID}_{50}$ of virus $\mathrm{ml}^{-1}$. After $60 \mathrm{~min}$ at $25^{\circ} \mathrm{C}$, the fish were transferred to $100 \mathrm{l}$ tanks with recirculating water $\left(24 \pm 1{ }^{\circ} \mathrm{C}\right)$. Fifty sheatfish fry treated in the same way, but without added virus, served as controls.

Light and electron microscopy. Samples of gills, heart, kidney, swim bladder, liver, spleen, brain, eye, muscle, and digestive tract, collected from fresh dead sheatfish 4 to $8 \mathrm{~d}$ after infection, were fixed in Bouin's solution, processed routinely and embedded in Paraplast ${ }^{(8)}$. Sections ( 3 to $5 \mu \mathrm{m}$ thick) were stained with hematoxylin and eosin ( $\mathrm{H} \& \mathrm{E})$, Masson's trichrome, Giemsa, and by the periodic acid-Schiff (PAS) method.

Additionally, organ samples taken as described above were fixed in $2.5 \%$ glutaraldehyde in $0.067 \mathrm{M}$ Soerensen-phosphate buffer ( $\mathrm{pH} 7.4)$ for $2 \mathrm{~h}$, washed 3 times with $0.2 \mathrm{M} \mathrm{D}(+)$-Saccharose-Soerensen-phosphate buffer, and postfixed with $1 \%$ osmium tetroxide 
in $0.1 \mathrm{M}$ cacodylate buffer for $2 \mathrm{~h}$. After dehydration in a graded acetone series, the specimens were embedded in Epon $812^{\circ}$. Semi-thin sections were stained with $1 \%$ toluidine blue in $1 \%$ borax. Ultrathin sections 'stained' with uranyl acetate and lead citrate were examined using a transmission electron microscope (Zeiss EM 109).

Reisolation of virus. Homogenates of whole sheatfish fry were diluted 1:10 in TC 199 medium containing $2 \%$ fetal calf serum and antibiotics $(1000 \mathrm{IU}$ penicillin $\mathrm{ml}^{-1}, 1000 \mu \mathrm{g}$ streptomycin $\mathrm{ml}^{-1}$ ). After centrifugation at $2000 \times g$ for $15 \mathrm{~min}$ at $4{ }^{\circ} \mathrm{C}, 10$-fold diluted supernatant fluid was inoculated into monolayers of BF-2 cell line. Infected cell cultures, incubated at $25^{\circ} \mathrm{C}$, were checked for cytopathogenic effects (CPE) daily. Infectivity titers, based on CPE observed at $1 \mathrm{wk}$, were calculated by the method of Reed \& Muench (1938).

\section{RESULTS}

\section{Clinical signs, mortality, and gross pathology}

Beginning on the fourth day after infection, fish showed anorexia, apathy, and ataxia, and they gathered at the heater, Generally, moribund fish moved slowly but occasionally they also showed sudden, rapid spiral movements. Eight days after infection, $100 \%$ of exposed fish had died (Fig. 1). At necropsy, liver and spleen of infected sheatfish were often swollen and pale, and there was no food in the digestive tract. Petechial haemorhages were common in the integument and were occasionally also present in eyes, barbels, and serosal surfaces.

\section{Histopathology and electron microscopy}

Spleen and haematopoietic tissue of kidney. In general all parenchymatous organs showed pathological alterations. The most severe lesions, however, were found in the spleen, kidney, and vascular system. The major consistent histopathological feature of this infection was a generalized acute necrosis of splenic and renal haematopoietic tissue. Sinus structure was hard to define as a result of destruction. Endothelial cells were swollen and dome-shaped with vacuolated cytoplasm. Periarteriolar reticulo-endothelial cells were vacuolated and often necrotic. The ellipsoids were associated with severe oedema (Fig. 2). Complete and incomplete viruses were present in the cytoplasm of ellipsoids (Fig. 3); they assumed stacked or crystalline arrays that were closely associated with the endoplasmic reticulum and mitochondria, indicating intracytoplasmic viral multiplication. Virus particles, assembled

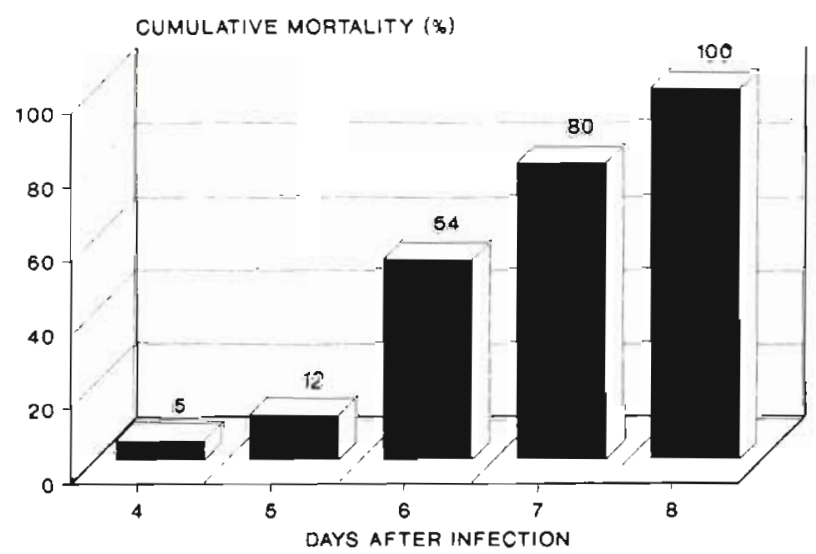

Fig. 1. Silurus glanis. Cumulative mortality of experimentally infected sheatfish fry after bath exposure to the isolated iridovirus

in the cytoplasm of endothelial cells, received envelopes by budding from the cell membrane (Fig. 4). Swollen mitochondria and extensive cytomembrane systems showing high electron density were found associated with virus particles, while in other endothelial cells virus particles were enveloped by a membrane. Mature virus particles were released by budding from the cell membrane (enveloped virus) or by lysis of the cell (non-enveloped virus); in some cases double membrane particles, possibly indicating endocytosis of viruses, were seen (Fig. 5). Only remnants of haematopoietic tissue remained in the renal interstitium, which exhibited large oedematous necrotic areas. In a few fry, small foci of macrophagelike cells were observed in the renal interstitium. Macrophages, monocyte-like cells, and granulocytes in the interstitial tissue harboured virus particles within phagosomes. Residual degenerating haematopoietic cells showed numerous virus particles and cytoplasmic viral subunit assembly (factory area) was observed.

Renal excretory system. The major histological change in the renal excretory system was degeneration of renal tubular and collecting-duct epithelia, but glomeruli were also affected. Cloudy swelling, hydropic degeneration, hyaline droplet degeneration, and necrosis were evident in the tubular epithelium. Bowman's space was either dilated and filled with eosinophilic deposits or occluded due to mesangial proliferation (Fig.6). Electron micrographs revealed virus particles in degenerate cells of the glomerular capillary loops, in podocytes, and in the parietal layer of Bowman's capsule or free in Bowman's space. Furthermore, virus particles were detected in lytic areas of tubular epithelial cells.

Gills. The most common lesion was hyperplasia and oedema (Fig. 7) of the gill epithelium, both in the primary and secondary lamellae. The proliferation of 

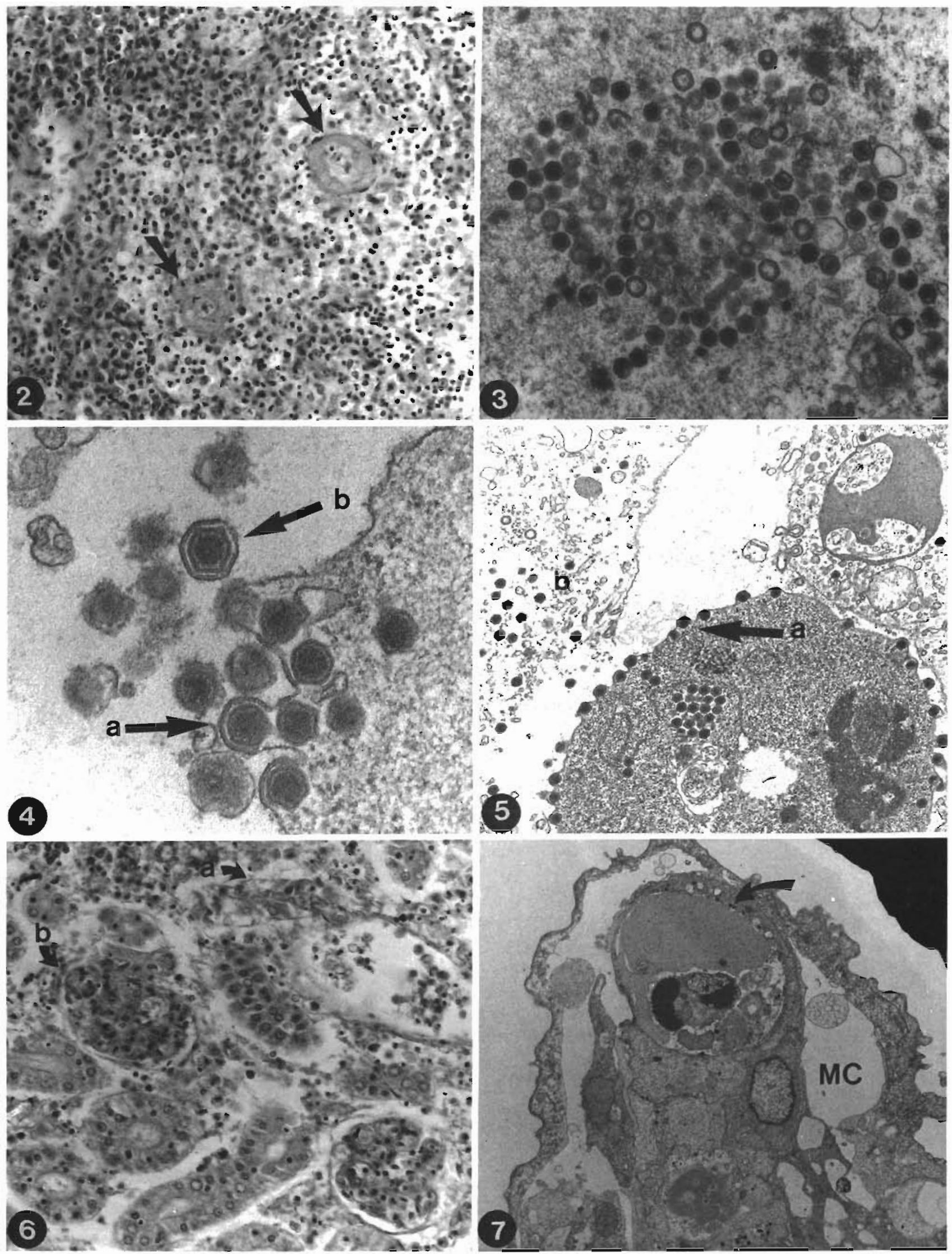

Figs. 2 to 7. Silurus glanis. Fig. 2. Spleen. Degeneration of vascular walls (arrows) and parenchymal haematopoletıc necrosis H \& E, $\times 300$. Fig. 3. Spleen. Complete and incomplete virus particles within the cytoplasm. TEM, $\times 27400$. Fig 4 Spleen. Viral particles receiving envelope by budding from the plasma membrane. a Budding process, b released vinon TEM, $\times 51200$. Fig. 5. Kidney. a: Release of enveloped viruses from the cell; b lytic area with non-enveloped virus particles. TEM, $\times 14700$. Fig. 6. Kidney. Renal excretory system. Degeneration of (a) renal tubules; (b) renal corpuscles $\mathrm{H} \& \mathrm{E} . \times 300$. Fig 7 Gills, secondary lamella. Virus particles (arrow) in endothelıum of marginal channel (MC) Oedema of respiratory epithelıum with 
epithelial and chloride cells was accompanied by degenerative changes and an infiltration of inflammatory cells. Epithelial cells of primary and secondary lamellae were partly necrotic and were occasionally detached from the basement membrane. The intercellular gaps of the secondary lamellae were extensive, and the interlamellar epithelium of primary lamellae tended to disintegrate. In some fish, blood lacunae of the secondary lamellae were dilated and congested. Eosinophilic, homogenous membrane-bound inclusions with a diameter of about 10 to $12 \mu \mathrm{m}$ were observed in the cytoplasm of proliferating cells. The spindle-shaped perichondrial cells were partly loosened and contained virus particles. Virus particles were also found in the cytoplasm of the pillar cells and in the degenerating endothelium of the branchial vessels (Fig. 7).

Skin. Hyperplasia of mucous cells and club cells was evident. The number of celis in the epidermis had increased enormously in comparison with control fish and most of these were necrotic, displaying round, homogenous, and eosinophilic inclusions of variable size. Zonal haemorrhages, a lympho-hystiocytic infiltration, and virus particles were detected in the hypodermis. Muscle fibers were hyalinized, especially in the dorsal part of the fish and under the lateral line organ. Under the electron microscope, degenerated and necrotic cells possessing phagosomes and phagolysosomes with virus were observed in the lesions.

Heart. Diffuse myocarditis was observed in the ventricular and atrial myocardium. Endocardial cells were activated and dome-shaped, while the underlying myocardium showed vacuolation and necrosis. A network of eosinophilic fibers was deposited in the subpericardial space, and epicardial fibrosis was present. Virus particles were found in atrial and ventricular endocardium and in myocardial cells.

Eye. Oedema and haemorrhage were evident in the retrobulbar space, and intracytoplasmic virus particles were present.

Liver and pancreas. Small foci of necrosis, accompanied by a lympho-histiocytic infiltrate, were observed particularly in periportal liver parenchyma and in the exocrine pancreas. Virus particles could be detected in the endothelium of periportal liver parenchyma and in the cells of the exocrine pancreas.

Brain. In some specimens, glial proliferation and spongiosis were observed. In such fish, meningeal blood vessels were congested and virus particles were observed in the vessel endothelium.

Digestive tract. Mild oedema was observed in the tunica propria and in the tela submucosa. Endoplasmic reticulum proliferation was evident in the gut epithelium and virus particles were present associated with cellular necrosis.
Control fish. No pathological changes and no virus particles were detected in the control fish examined.

\section{Reisolation of virus}

BF-2 cells, inoculated with 10-fold dilutions of homogenates of infected sheatfish, showed extensive CPE consisting of cytolysis 48 to $72 \mathrm{~h}$ after infection at $25^{\circ} \mathrm{C}$. Infectivity titers obtained ranged from 6.5 to 8.2 $\log _{10} \mathrm{TCID}_{50} \mathrm{ml}^{-1} 7 \mathrm{~d}$ after infection. No CPE were observed in BF-2 cells inoculated with homogenates from control fish.

\section{DISCUSSION}

Iridovirus infections are known to occur in several species of teleost fish (Ahne 1985). The best-known of these are lymphocystis (LD) and viral erythrocytic necrosis (VEN). Lymphocystis is a viral infection causing hypertrophy of individual infected fibroblasts (Weissenberg 1920). Viral erythrocytic necrosis is characterized by altered erythrocytes carrying virus particles (Walker 1971). The sheatfish pathological picture resembled that seen in diseases associated with the cichlid-iridovirus (Leibovitz \& Riis 1980), the perchiridovirus (Langdon et al. 1986), and the Japanese eel iridovirus (Sorimachi \& Egusa 1982). In all cases, haemorrhages and necrosis occurred in several tissues of the infected fish. However, when the pathological and clinical pictures were considered, including the haemorrhaging and necrosis in liver, pancreas, gastrointestinal tract, and haematopoietic tissue, and the sudden high mortality of infected sheatfish, the disease most closely resembled epizootic haematopoietic necrosis (EHN), a viral disease described in redfin perch Perca fluviatilis (Langdon \& Humphrey 1987).

Langdon et al. (1988) reported outbreaks of a disease due to an EHN-like iridovirus in cultured rainbow trout Oncorhynchus mykiss. The disease was associated with a vacuolating encephalopathy, and focal necrosis in liver, red and white splenic pulp, gastrointestinal epithelium, and renal haematopoietic tissue. Langdon (1989) examined the epizootiology of EHNV by experimental transmission and pathogenicity trials in Perca fluviatilis and 11 other Australian teleosts. Four species (Macquaria australasica, Bidyanus bidyanus, Galaxias olidus, $O$. mykiss) were shown to be highly susceptible to the disease by bath exposure.

Both the sheatfish iridovirus and EHNV were transmitted via water, producing high mortalities with similarities in pathology within a few days. In both cases the epizootics induced a serious population decline in infected fish. However, it is not yet known 
whether the sheatfish virus would cause losses in sheatfish at life stages other than the fry stage.

In the present investigation it was shown that the iridovirus isolated from sheatfish fry is endotheliotropic. Kidney and spleen are apparently the major target organs. The multiplication of the virus in the endothelium results in loosening of the capillary walls and leads to an increase in the permeability of blood vessels. The result is oedema, haemorrhagic diathesis, and peripheral circulatory failure. These pathological features are similar to those described for African swine fever, also caused by an iridovirus infection (Coggius 1974). In addition to effects on the endothelial cells, a generalized destruction of the haematopoietic tissue of kidney and spleen was observed in infected sheatfish. The severe virulence of the virus in experimentally infected fish illustrates the hazard of iridoviral infection in fish.

Acknowledgements. The authors thank Miss S. Eßbauer and Miss C. Kühnhauser for skilful technical help.

\section{LITERATURE CITED}

Ahne, W. (1985). Virusinfektionen bei Fischen: Ätiologie, Diagnose und Bekämpfung. J. Vet. Med. B 32: 237-264

Ahne, W., Schlotfeldt, H. J., Thomsen, I. (1989). Fish viruses: isolation of an icosahedral cytoplasmic deoxyribovirus from sheatfish (Silurus glanis). J. Vet. Med. B 36: 333-336

Ahne, W., Ogawa, M., Schlotfeldt, H. J. (1990). Fish viruses: transmission and pathogenicity of an icosahedral cytoplasmic deoxyribovirus isolated from sheatfish (Silurus glanis). J. Vet. Med. B 37: 187-190

Békési, L., Kovács-Gayer, E., Rátz, F., Turkovics, O. (1981). Skin infection of the sheatfish (Silurus glanis) caused by a herpes virus. Proceedings of an international seminar on fish, pathogens and environment in European polyculture. Szarvas, Hungary, p. 59-69

Responsible Subject Editor: Dr T Evelyn, Nanaimo, B.C., Canada
Coggius, L. (1974). African swine fever virus. Pathogenesis. Prog. med. Virol. 18: 48

Fijan, N., Matasin, N., Jeney, Zs., Oláh, J., Zwillenberg, L. O. (1981). Isolation of Rhabdovirus carpio from sheatfish (Silurus glanis) fry. Proceedings of an international seminar on fish, pathogens and environment in European polyculture. Szarvas, Hungary, p. 48-58

Jørgensen, P. E. V., Olesen, N. J., Ahne, W., Lorenzen, N. (1989). SVCV and PFR viruses: serological examination of 22 isolates indicates close relationship between the two fish Rhabdoviruses. In: Ahne, W., Kurstak, E. (eds.) Viruses of lower vertebrates. Springer Verlag, Heidelberg, p. $349-366$

Langdon, J. S., Humphrey, J. D., Williams, L. M., Hyatt, A. D., Westbury, H. A. (1986). First virus isolation from Australian fish: an iridovirus-like pathogen from redfin perch. Perca fluviatilis L. J. Fish. Dis. 9: 263-268

Langdon, J. S., Humphrey, J. D. (1987). Epizootic haematopoietic necrosis, a new viral disease in redfin perch, Perca fluviatilis L., in Australia. J. Fish. Dis. 10: 289-297

Langdon, J. S., Humphrey, J. D., Williams, L. M. (1988). Outbreaks of an EHNV-like iridovirus in cultures rainbow trout, Salmo gairdneri Richardson, in Australia. J. Fish. Dis. 11: $93-96$

Langdon, J. S. (1989). Experimental transmission and pathogenicity of epizootic haematopoietic necrosis virus (EHNV) in redfin perch, Perca fluviatilis L., and 11 other teleosts. J. Fish. Dis. 12: 295-310

Leibovitz, L., Riis, R. C. (1980). A new viral disease of aquarium fish. Fish Health News 9(1): 4-6

Reed, L. J., Muench, H. (1938). A simple method of estimating fifty percent endpoints. Am. J. Hyg. 27: 493-502

Sorimachi, M., Egusa, S. (1982). Characteristics and distribution of viruses isolated from pond-cultured eels. Bull. natn. Res. Inst. Aquacult. 3: 97-105

Walker, R. (1971). PEN, a viral lesion of erythrocytes. Am. Zool. 11: 707 (Abstract)

Weissenberg, R. (1920). Lymphocystisstudien (infektiöse Hypertrophie von Stützgewebzellen bei Fischen) I. Die reifen Geschwülste bei Kaulbarsch und Flunder. Lymphocystisgenese beim Kaulbarsch. Arch. microsk. Anat. 94: 55-134

Manuscript first received: March 21, 1990

Revised version accepted: October 2, 1990 